УДК 78.087.68(100=161.2)

DOI:

Зоряна Гнатів, кандидат філософських наук, доиент кафедри методики музичного виховання $і$ диригування, Дрогобицького державного педагогічного університету імені Івана Франка

Ірина Чернова, магістр педагогічної освіти, вчитель музичного мистецттва Роздільської ЗОШ, керівник вокальної студії та викладач вокалу “Школи раннього творчого розвитку “Малятко” Новороздільського будинку дитячої та юнацької творчості

\title{
ОБ'ЄКТИВНІСТЬ ЕСТЕТИЧНОГО В ДІЯЛЬНОСТІ УКРАЇНСЬКИХ ХОРОВИХ ОСЕРЕДКІВ ЗАРУБІЖЖЯ
}

Багатство феномену естетичного утверджує культивування иінностей, категорій прекрасного, духовного, спонукає до переформатування людської психіки, людської дійсності, людського буття. Геніальність творів мистецтва, щуо виступає наслідком особливостей людського розуму складають партитуру світових симфоній та є могутнім чинником процесу едукації. Автори піднімають проблему хорової практики украӥнської діаспори, висвітлення якої сприяє комплексним мистецько-освітнім дослідженням питань феноменів естетичного, розумінням світоглядних моделей культури, теорії та практики музичного виховання mойо.

Ключові слова: хорове мистецтво; диригенти; українська діаспора; національна культура; естетичні üінності.

Jim. 8.

Zoriana Hnativ, Ph.D. (Philosophy), Associate Professor of the Teshnique of Musical Education and Conducting Department Drohodych Ivan Franko State Pedagogical University

Iryna Chernova, Master Student of Pedagogical Education, Teacher of Music Art of Rozdil School, Head of Vocal Studio and Vocal Teacher of the "School of Early Creative Development "Malyatko" of Novorozdil House of Children's and Youth Creativity

\section{OBJECTIVITY OF THE AESTHETIC IN THE ACTIVITIES OF UKRAINIAN CHOIR CENTERS OF FOREIGN COUNTRIES}

The richness of the aesthetic phenomenon affirms the cultivation of values, categories of the beautiful and the spiritual as well as encourages the reformatting of the human psyche, human reality, and human existence. The artistic and aesthetic values developed by mankind throughout history are the source of development of all civilizations. The genius of works of art, which is a consequence of the peculiarities of the human mind, make up the score of world symphonies.

Musical art, in particular choral singing, is an integral part of the general cultural process of society. The phenomenon of Ukrainian singing is celebrated all over the world for its melodiousness and uniqueness. The functioning of Ukrainian choirs outside our country has a long history and full development. Original samples of Ukrainian culture are nurtured and transmitted by the artistic potential and accumulated abroad.

Choral culture of Ukraine of the XIX-XX centuries manifested itself far beyond its ethnographic lands. Creating a real image of the unreal Ukrainian choral singing is known in all corners of the planet. In many countries, choirs led by people from Ukraine, who found themselves there by fate, found their creative expression. Conductors organized from groups of newly arrived singers groups, or existing choirs, orchestras, which were based on Ukrainians, different in profession, education, but-patriots of their culture, people, faith. Belief in the state of Ukraine.

Choral conductors of the diaspora presented Ukrainian music to the civilized world in different ways. It was performed by both amateur and professional groups. Conductors and instrumentalists performed complex works of world classics. Among the famous artists are M.Haivoronsky, L. Turkevych, O. Koshyts, I. Sonevytsky, M. Antonovych, A. Hnatyshyn, V. Kolesnyk, M. Dytyniak and many others, who with their efforts raised large vocal-symphonic, instrumental, choral, opera and oratorio canvases.

Under the direction of choral composers-conductors - musicians of the Ukrainian diaspora-the best examples of choral art, including Liturgy, opera, symphony, sounded at all known World Forums: in Rome on the occasion of the 1000th anniversary of the baptism of Rus-Ukraine, at various state celebrations and anniversaries in the USA, Canada, Austria, Poland, England, Australia, Germany, France, Holland, the Czech Republic, Slovakia, etc. 


\section{ОБ’ЄКТИВНІСТЬ ЕСТЕТИЧНОГО В ДІЯЛЬНОСТІ \\ УКРАЇНСЬКИХ ХОРОВИХ ОСЕРЕДКІВ ЗАРУБІЖЖЯ}

An educational research on the phenomena of aesthetics, understanding of worldview models of culture, theory and practice of music education, etc.

Keywords: choral art; conductors; Ukrainian diaspora; national culture; aesthetic values.

П остановка проблеми. Аналіз внутрішньої структури мистецтва спонукає до осмислення прекрасного, яке твориться людською діяльністю. В цьому випадку йдеться про феномен хорового мистецтва та його творців - композиторів, диригентів, співаків, які за волею долі жили та творили за межами своєї країни.

Тривалий час багато видатних діячів українського мистецтва талановитих українських композиторів, диригентів, педагогів і музичногромадських діячів були у забутті. На сьогоднішній день життя та творчість деяких 3 них ще недостатньо вивчені і маловідомі широкому загалу, адже це діяльність у несприятливих умовах чужини, не без впливу існуючої державної культури, звичаїв корінного народу тощо. Відтак, завдяки рідним, знайомим, друзям композиторів, окремим музикознавцям й науковцям вдається відкривати той творчий пласт мистецького доробку, який зайняв належне місце в еволюції української музичної культури. Виїхавши свого часу з власної волі чи вимушено, мистці знаходили та продовжують знаходити можливість реалізувати свої творчі задуми і плани. Багато 3 них проводять активну музично-просвітницьку роботу, виступають з концертами, пишуть музику, організовують хори, конкурси, фестивалі тощо.

Аналіз наукових праць 3 проблемами дослідження. Діяльність українських хорових диригентів діаспори розглядається багатьма дослідниками передусім як музично-педагогічна, громадсько-просвітницька, регентська. Деякі відомості про хорову культуру української діаспори подані в працях В. Андрущака, М. Барана, М. Бурбана, О. Кошиця, В. Луціва та ін. Вагомою працею, яка побачила світ у 2012 р., стала монографія Г. Карась "Музична культура української діаспори у світовому часопросторі XX ст.”, в якій на основі багатої джерельної бази викладено результати комплексного дослідження музичної культури української діаспори, відтворено процес iіi становлення, розвитку та особливості в різних країнах світу, здійснено реконструкцію більш як столітнього музичного життя українців за кордоном.

Феномен хорової культури українського зарубіжжя охоплює значний часовий період та $€$ широкомасштабним, тому кожен $з$ дослідників, працюючи над означеною проблемою відкриває все нові і нові горизонти вагомого доробку українського мистецького життя за кордоном, свідчать про його самобутність, ментальність, змістовність. Вихідним пунктом нашого аналізу $\epsilon$ естетично-діяльнісний феномен мистецтва, відтак хорового мистецтва української діаспори, що складає естетичну свідомість, тобто породжуючу, формуючу силу існування людського роду, народу, нації. "Художні формотворчі характеристики мистецтва визначають його змістовний вимір. Ці елементи фіксують як позитивний, так i негативний досвід самовизначення людини й людського роду. Гуманізація людини, формування ії самосвідомості і здатності до самовизначення, гуманістичного світоставлення полягає, передусім, у розвитку естетичної свідомості та чуттєвості" $[1,6]$.

Мета статті - висвітлити мистецьку діяльність творців української хорової культури за кордоном, зокрема Англії та США, як важливе джерело естетичної комунікації та духовної єдності народу в контексті розвитку сучасних освітніх процесів.

Виклад основного матеріалу. У світлі сучасних бачень розвитку освіти та науки, мистецтва та культури, відтак українського музичного діаспорознавства, одного $з$ найбільш пріоритетних та перспективних нових напрямів у галузі гуманітарних досліджень (факт зародження якого зазначено постановою Президії НАН України від 16.03.1994 р.) [6, 112], ми звертаємось до цікавих сторінок української музичної культури зарубіжжя, опираючись на необхідність відтворення музично-естетичних та історичних координат національної самобутності. Як зазначає Г. Карась: "Історичний розвиток української культури передбачає виняткові, специфічні обставини життедіяльності етноспільности. Самобутні зразки української художньої культури формувались не лише на рідній землі, у нерозривному зв'язку зі своїм народом, але й створювались поза ії межами митцями, що силою обставин були відірвані від батьківщини, поставлені у дуже непрості соціально-культурні і суспільні умови" $[4,15]$.

Важливу роль у розвитку хорової культури в діаспорі відігравало культурно-мистецьке середовище. Українські хори в Англії виникли в післявоєнний період із числа українських емігрантів. Хори створювались та існували у місцевих осередках осілості українців - вони виконували функції і церковних хорів.

Серед відомих колективів - український чоловічий самодіяльний репрезентативний хор 
Союзу українців у Великій Британії. Слід зазначити, що Союз Українців у Великій Британії (СУБ) [Association of Ukrainians in Great Britain] - найбільша українська громадська організація в Сполученому Королівстві (СК), яка об'єднує етнічних українців-мешканців СК та прихильників України в цій країні. Організація була заснована 19-20 січня 1946 р. в Единбурзі. Від початку існування СУБ займається проведенням різноманітної культурно-освітньої діяльності 3 метою "збереження національних традицій та ідентичності серед місцевого українства і представлення української культури в британському суспільстві. У 1954 р. при відділах СУБ діяли 17 хорів, 14 танцювальних гуртків і 15 театральних колективів. Вони виступали на концертах та інших культурних заходах, організованих як місцевими Відділами, так і Головною Управою (часто для відзначення роковин подій з історії України), а також поза українською громадою, зокрема на міжнародних фестивалях і конкурсах, в тому числі за кордоном. У пізніших роках більшість згаданих колективів перестали існувати, а на їх місце прийшли нові, створені з нащадків післявоєнних поселенців. Деякі колективи, однак, ще багато років діяли при СУБ, зокрема хор "Гомін” і надалі існуючий танцювальний колектив “Орлик” у Манчестері та хор “Діброва” в Брадфорді” [7].

Високим рівнем виконанням та різноманітним хоровим репертуаром славився хор "Гомін”. У виконанні хору звучали: хоровий концерт №15, “Херувимська" Д. Бортнянського, "У неділеньку святую”, "Прометей”, "Рано-вранці", “Бурлака" К. Стеценка, “Зокрушків”, “Туляли” О.Нижанківського, “Огні горять” С. Воробкевича, хор “Закувала та сива зозуля” з музичної картини до п’єси Т. Шевченка “Вечорниці” П. Ніщинського, обробки народних пісень, колядки, щедрівки, стрілецькі пісні, пісні УПА.

Хор "Гомін" заснований із числа українцівемігрантів у 1949 р. Я. Бабуняком у м. Манчестер. Від 1949 до 1964 р. хором керували Я. Бабуняк та Є. Пасіка. У 1964 р. Є. Пасіка переїжджає до США й відтоді керівником колективу залишається Я. Бабуняк. 29 серпня 2012 р. світ дізнався про смерть відомого диригента Я. Бабуняка. Поховали митця в м. Манчестер.

Протягом 1980-1990 рр. у культурно-освітній діяльності ОбВУ (Об'єднання бувших Вояків Українців) брали участь такі мистецькі ансамблі, колективи і групи з різних місцевостей Великої Британії: Чоловічий хор “Діброва”- Брадфорд, хор Осередку СУМ “Боян” - Ноттінггам, хор гуртка ОУЖ “Барвінок” - Лестер, дівочий хор
“Трембіта" Олдгам, мішаний хор "Сурма" Лондон, мішаний хор в Коентрі, чоловічий хор в Кіхлей, жіночий хор “Волошки” - Ковенрі, чоловічий хор в Лестер, жіночий хор в Рочдейлі, хор “Луна" - Олдгам, хоровий гурток ОУЖ Тодморден, хоровий гурток СУБ - Тодморден, музико-співочий гурток в Нортгамптоні. Культурно-освітнім референтом Головної Управи Об'єднання бувших Вояків Українців у Великій Британії працював безперебійно В. Нагайло [5, 37].

Серед відомих керівників хорових колективів Д. Марків (жіночий хору Брадфорді), С. Замулінський (мішаний хор “Діброва”). В м. Ковентрі керівником жіночого хору був М. Костюк, в м. Лестері хором “Барвінок” керував Х. Кіллам, у м. Манчестері існував жіночий хор під орудою М. Цебрій, у м. Олдгайм жіночим хором керував К. Душа, у м. Рочдейл відомий жіночий хор під керівництвом О. Паращак, у м. Тодморден - жіночий хор під керівництвом А. Білецької. Всі ці хори - учасники Організації Українських Жінок Великої Британії (ОУЖ), заснованої у 1963 р.

Серед сучасних хорів в Англії Соборний хор при Українській Католицькій Єпархії Пресвятої Родини в Лондоні. Названий хор був організований і вперше публічно заспіваний під час Великодніх служб у 2000 р. під керівництвом П. Кочанського і в цьому ж році вперше публічно виступив під час Великодніх служб. 2 лютого 2006 р. за благословенням єпископа П. Хомницького хор отримав назву “Промінь Надіï”. У ньому бере участь відомий сучасний композитор Г. Курцеба. Партитура Курцеби з Божественної Літургії святого Іоанна Златоуста була вперше виконана 30 липня 2006 р., $з$ того часу їі співають численні хори в Україні та США. “Промінь надії” регулярно виступає на різних заходах української громади, включаючи концерти в Лондоні, Глостері, Вулвергемптоні, Ноттінгемі та ін. Крім того щонеділі о 10.00 виконує Божественну Літургію в соборі Української Католицької Єпархії Пресвятої Родини в Лондоні. Своїми музичними зусиллями цей хор, як і багато інших українських хорів демонструє англійській аудиторії багату історію та духовність священної української хорової музики.

Перший український хор кількістю 50 осіб на теренах США був заснований в м. Шенандоа (Пенсільванія) В. Сименовичом. У виконанні колективу в 1894 р. вперше на американській землі у м. Шамокін прозвучав гімн “Ще не вмерла Україна” М. Вербицького. Українські хори також існували в Нью-Йорку, Філадельфії, Пітсбургу, Чикаго, Нью-Арку, Перт-Амбої.

Якісний злет у пропаганді українського 
хорового співу в Америці відбувся в 1922 р., коли сюди прибув Український національний хор під керівництвом Олександра Кошиця. Колектив тричі виходив переможцем у щорічному конкурсі аматорів співу 3 чотирьох штатів, який влаштовувався газетою “Chicago Tribune” (Чикаго трібюн). У газеті відзначалось, що за своєю злагодженістю, чистотою тону це один із найкращих хорів в Америці. 31922 р. в США керував хорами, оркестрами, український композитор, диригент і педагог Павло ПеченігаУглицький, виходець із Харківщини.

У 1923 р. в Америці розпочалася діяльність М. Гайворонського. Як пише В. Витвицький: “Свою диригентську діяльність Гайворонський провадив з різними українськими хорами, зокрема, деякий часочолював Українськийхорім. М. Леонтовича. В програмі одного 3 концертів виконав інсценізацію народної “Пісні про Байду” у своїй обробці для двох солістів і хору” [3, 9]. Наприкінці 1920-х pp. М. Гайворонський зумів об’єднати українські хори, які функціонували недалеко від Нью-Йорка (керівниками цих колективів були Т. Каськів, А. Гела, М. Буката, М. Фатюк, В. Мельничук, С. Грабар, П. Щавінський). Під його керівництвом була створена організація “'З’єднаних українських хорів”, членами якої стали 50 хорів, поділених на округи: Нью-Йорк, Філадельфія, Клівленд, Пітсбург, Дітройт, Чикаго.

У 1927 р. в Детройті засновується хор “Думка”, яким диригував I. Атаманець. У Чикаго диригентом українських хорів був М. Бенецький, у Нью-Йорку - Ю. Кириченко, в Олифанті Л. Сорочинський. В 30-их рр. відбулися виступи зведених українських церковних хорів під керівництвом М. Гайворонського.

У 1950 р. засновується ще один хор “Думка" в Нью-Йорку, яким керували О. Микитюк, Л. Крушельницький, І. Задорожний, І. Недільський. У 1950-1951, 1965-1966, 1973-1974 pр. диригентом хору був I. Соневицький - відомий композитор, мистецтвознавець, диригент, співзасновник та викладач Українського Музичного Інституту в Нью-Йорку, а в 1959-1961 рр. його директор.

70-річчя видатного хору було відзначено 6 жовтня 2019 р. святковим концертом у НьюЙорку. Генеральне консульство України в НьюЙорку повідомляло: “За сім десятиліть хор “Думка" став одним із символів української громади у США, який активно популяризує на теренах Америки та за їі межами музичну культуру українського народу, насамперед хорове мистецтво. За невтомну працю у пропаганді української музики в Америці, Канаді та Європі хор “Думка” нагороджений державною премією імені Миколи Лисенка". 28 років художнім керівником та диригентом хору є випускник Львівської консерваторії Василь Гречинський. Серед особистих заслуг Маестро Гречинського - заснування дитячої хорової студії “Молода Думка", виступи якої користуються незмінною популярністю серед українців США” [8].

У 1953 р. у Філадельфії А.Рудницький організовує хор “Кобзар”. До відомих українських хорів у США належать: хор ім. М.Леонтовича “Трембіта” (Нью-Йорк), “Трембіта” (Детройт), “Дніпро” ім. М. Лисенка (Клівленд), “Прометей” (Філадельфія), “Сурма” (Чикаго), “Кобзар” (ЛосАнджелес).

У США продовжили свою діяльність диригенти, композитори, священикиВ. Безкоровайний (Буффало), Т. Губицький (Детройт), К. Цепенда (Детройт), Я. Барнич (Клівленд), О.Берник (НьюЙорк), В. Божик (Лос-Анджелес), І. Задорожний (Чікаго, Філадельфія,Нью-Йорк, Стемфорд), О. Залеський (Буффало), З.Злочовський(Філадельфія),Ю.Оранський (Філадельфія), Є. Пасіка (Ротчестер) [2, 59]. Тут ведуть активну концертну діяльність диригенти А. Бриттан, С. Комірний, з церковним хором працює О. Боднарчук (Клівленд) - випускниця Дрогобицького музичного училища. В Чикаго популярними є хор ім. М. Лисенка кафедрального собору(кер.Д.Іванков), “Славута” (кер.Ю. Яримович), церкви св. Йосафата (кер. Ю. Позняк), хор “Прометей” (кер. Р. Андрушків).

Цікава сторінка в українському музичному житті у США - діяльність капели бандуристів ім. Т. Шевченка (Детройт). На початку творчого шляху вона складалася 3 колишніх учасників довоєнної Полтавської капели, частина якої, на чолі з Г. Китастим, прибула до США в 1949 р. Капела бандуристів ім. Т. Шевченка гідно спричинилася до сучасного українського національного відродження. 31984 р. нею керував відомий український митець В. Колесник. Колектив неодноразово бував у Свропі, а також в 1991 р. та 1994 р. в Україні.

Отже, хорова культура України як складова загальнокультурного історичного процесу проявила себе і за своїми географічними межами, де на чужих землях завдяки ініціативі та праці українських митців звучала українська хорова музика, функціонували нові хори, організувались колективи $з$ числа новоприбулих співаків, працювали хори, оркестри. Основу їх складали і складають українці, різні за фахом, освітою, але - патріоти своєї культури та народу, своєї віри та цінностей. У різних куточках світу завдяки чуттєвому втіленню українське мистецтво $\epsilon$ окремим суб'єктом 3 його внутрішньою 
життєвістю. Естетичні ідеї духовності, патріотизму, вічних цінностей закладені в партитурі хорового мистецтва, зумовлюють його зосередження на розкритті багатства духовного світу людини, нації, держави. Вивчення мистецькоосвітніх проявів українського суспільства, міжкультурної комунікації сприяе більш ефективному вихованню сучасної особистості та формуванню людських цінностей життя.

\section{ЛIТЕРАТУРА}

1. Бітаєв В. Духовна культура України та їі гуманістичний потенціал. Духовна культура як домінанта украӥнського життетворення: зб матеріалів всеукр. науково-практичної конференції, Київ 22-23 грудня 2005 р. Київ: ДАКККіМ, 2005. Ч.1 356с. С.6-9

2. Бурбан М. Хорова культура української діаспори: навч. посібник. Дрогобич: НВЦ "Каменяр", 2003. 94c.

3. Витвицький В. Українське хорове мистецтво. Мu і свіm. 1963. листопад. С.4-14.

4. Карась Г. Музична культура української діаспори у світовому часопросторі XX століття: монографія. Івано-Франківськ: Тіповіт, 2012. 1664 с.

5. Об'єднання бувших Вояків Українців у Великій Британії / під заг.ред. д-р Святомира М. Фостуна. Альманах. Лондон, 1990. 351с.

6. Проблеми вивчення української діаспори в установах України. Постанова президії АН України від 16 березня 1994p. Українська діаспора. Київ- Чікаго: Інститут соціології НАН України, Редакція Енциклопедії української діаспори при НТШ (США), 1994. Ч.5. С.111-115.

7. Українці в Сполученому Королівстві / За матеріалами інтернет-енциклопедії. URL: http:// www.ukrainiansintheuk.info/ukr/03/sub-u.htm

8. 70-річчя заснування українського хору “Думка" (м. Нью-Йорк, США) URL: https:// www.ukrinform.ua/rubric-diaspora/2797059-unujorku-vidznacili-70ricca-zasnuvanna-ukrainskogohoru-dumka.html

\section{REFERENCES}

1. Bitaiev, V. (2005). Dukhovna kultura Ukrainy ta yii humanistychnyi potentsial [Spiritual culture of Ukraine and its humanistic potential]. Dukhovna kultura yak dominanta ukrainskoho zhyttietvorennia: zb materialiv vseukr. naukovo-praktychnoi konferentsii, Kyiv 22-23 hrudnia 2005 r.- Spiritual culture as a dominant of Ukrainian life: a collection of materials all-Ukrainian. scientific-practical conference, Kyiv, December 22-23, 2005. Kyiv, part.1 356 p. pp.6-9. [in Ukrainian].

2. Burban, M. (2003). Khorova kultura ukrainskoi diaspory: navch. posibnyk [Choral culture of the Ukrainian diaspora: textbook. manual]. Drohobych, 94 p. [in Ukrainian].

3. Vytvytskyi, V. (1963). Ukrainske khorove mystetstvo [Ukrainian choral art]. We and the world.pp.4-14. [in Ukrainian].

4. Karas, H. (2012). Muzychna kultura ukrainskoi diaspory u svitovomu chasoprostori XX stolittia: monohrafiia [Musical culture of the Ukrainian diaspora in the world time-space of the XX century: monograph]. Ivano-Frankivsk, 1664 p. [in Ukrainian].

5. Obiednannia buvshykh Voiakiv Ukraintsivu Velykii Brytanii (1990). [Association of Former Ukrainian Soldiers in Great Britain. Almanac.]. (Ed). Sviatomyr \& M. Fostun. Almanac.London, 351p. [in Ukrainian].

6. Problemy vyvchennia ukrainskoi diaspory v ustanovakh Ukrainy. Postanova prezydii AN Ukrainy vid 16 bereznia 1994r. [Problems of studying the Ukrainian diaspora in Ukrainian institutions. Resolution of the Presidium of the Academy of Sciences of Ukraine of March 16, 1994]. Ukrainian diaspora. Kyiv-Chikaho, part.5. pp.111-115. [in Ukrainian].

7. Ukraintsi v Spoluchenomu Korolivstvi [Ukrainians in the United Kingdom]. According to the online encyclopedia. Available at : http:// www.ukrainiansintheuk.info/ukr/03/sub-u.htm [in Ukrainian].

8. 70-richchia zasnuvannia ukrainskoho khoru "Dumka" (m. Niu-York, SShA) [70th anniversary of the Ukrainian choir "Dumka" (New York, USA)].]. Available at : https://www.ukrinform.ua/rubricdiaspora/2797059-u-nujorku-vidznacili-70riccazasnuvanna-ukrainskogo-horu-dumka.html[in Ukrainian].

Стаття надійшла до редакції 15.10.2021

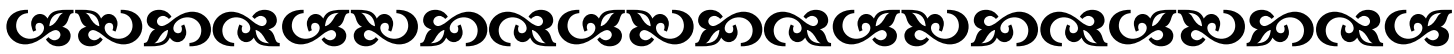

"Учень запитав: “чи можна все життя керувати одним словом?" Вчитель відповів: “ㄱе слово взаємність. Не роби іншим того, чого не бажаєш собі".

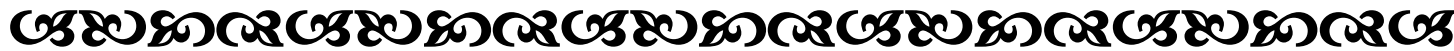

